\title{
Magyar állam versus csehszlovák állam: ungvári népgyülések 1918. november 9. és 1919. május 8.
}

\author{
Gulyás László*
}

\begin{abstract}
First Czechoslovakian Republic versus Hungarian Kingdom: Ungvár, November 9, 1918. and Ungvár, May 8, 1919. The collapse of the AustroHungarian Empire began in October of 1918, raising a number of territorial questions from Bukovina to Fiume. One of these was the issue of Subcarpathia/Kárpátalja. During the

autumn of 1918, many states - the forming Czechoslovakia and Poland, the various competing Ukrainian state formations - were aiming to get hold of Kárpátalja. At the same time, Hungarian politicians worked to keep the region within the Hungarian state. On November 6, 1918 in Ungvár, the Ruthenian population made a decision that was definitely favourable for the Hungarian cause. Our paper presents this decision, its background and consequences.
\end{abstract}

Keywords: Great War (1914-1918), history of Central-Europe, birth of the First Czechoslovakian Republic, activity of Ruthenians at 1918-1919

\section{Bevezetés}

1918 őszén számos történelmi régió/terület - a Bánságtól Székelyföldig - sorsa kérdésessé vált. Ezek egyike volt a dualista korszakban Északkelet-Felvidéknek (Kárpátalja) nevezett régió is. ${ }^{1} 1918$ őszén több állam - az éppen formálódó Csehszlovákia, a különféle egymással is vetélkedő ukrán államkezdemények, a születőfélben lévő Lengyelország - akarta megszerezni Kárpátalját. Ezzel párhuzamosan a magyar politikusok azért tevékenykedtek, hogy a területet a magyar állam keretei között tartsák.

A régió rutén lakossága 1918. november 6-án Ungvárott a magyar kormány törekvései számára kifejezetten kedvező döntést hozott. Ezzel szemben, néhány hónappal később 1919 májusában mégis a csehszlovák államhoz történő csatlakozást mondták ki.

Tanulmányunkban ezen két ungvári döntést, azok elözményeit és következményeit mutatjuk be.

\footnotetext{
* Intézmény: Szegedi Tudományegyetem Juhász Gyula Pedagógusképző Kar Email: laszlo.gulyas65@gmail.com

${ }^{1} 1918$ előtti történetéről lásd Gulyás László 2009, 65-75.; Gulyás László 2015/a, 191-200.
} 


\section{Előzmények: a rutének és a magyar állam 1914-1918}

A Nagy Háború (1914-1918) alatt a rutén nép túlnyomó többsége lojális volt a magyar államhoz. ${ }^{2}$ Értelmiségi rétegük - melyeknek nagy része a görög katolikus papság soraiból került ki - jól együttmüködött a magyar politikai elittel. ${ }^{3}$ A rutén vezető réteg magyarbarátságát jól mutatja, hogy Volosin Ágoston - aki a későbbiek során a magyar állam ellen lépett fel - a Munkács Egyházmegyei Kántor Tanító Egyesület 1918. szeptember 5-i közgyülésén az alábbi kijelentetést tette: ,Mi büszkén állapítjuk meg, hogy a hazai rutén nép szembeszáll a kísértés, a csábitás erejének, az ellenséges betörés alkalmával sziklaszilárdan örizte meg hazafias tradicióit és nem esett a hit- és hazaellenes (értsd Magyarország - G. L.) áldemokrácia tüzébe. " 4 Ezt a magatartást az egyszerü rutén nép is követte. A rutén katonák pedig hüséges és megbízható tagjai voltak a Monarchia hadseregének.

A cseh-, illetve ukrán-/oroszbarát irányzatok bár léteztek, nagyon gyengék voltak, képviselőik, mind a hazai rutén vezetők, mind az egyszerü rutén nép soraiban kisebbségben voltak. Ekkor még a rutének között egyértelmüen a magyarbarát irányzat volt a legerősebb. ${ }^{5}$

\section{Az ungvári népgyülés: 1918. november 6.}

1918. október 31-én az őszirózsás forradalom eredményeképpen Károlyi Mihály lett a miniszterelnök. Kormányában ,a Magyarországon élö nemzetek önrendelkezési joga előkészitésével megbizott tárca nélküli minister”-ré Jászi Oszkárt nevezte ki. Jászi koncepciója a nemzetiségi jogok megadása volt, Magyarország területi integritásának megőrzésével. Ennek jegyében autonómiát kínált a nemzetiségeknek, remélve, hogy azok majd „otthon érzik” magukat az új, demokratikus Magyarországon, azaz a magyar állam keretei között maradnak.

Ha az Északkeleti-Felvidéket nézzük, akkor kijelenthetjük, hogy ott a helyzet november elején kedvezően alakult Jászi törekvéseinek megvalósításához. 1918. november 6-án Ungvárott megalakult a Magyar-Rutén Néptanács (másnéven Magyarországi Rutének Néptanácsa), melynek elnökévé Szabó Simont, illetve titkárává Avgusztin Volosint választották. Programjuk az alábbi négy ponttal irható le: ${ }^{6}$

1. Ragaszkodás Magyarország területi integritásához. Ezt az alábbi módon fogalmazták meg: „A magyarországi rutén nép ragaszkodik az őshaza integritásához, és tiltakozik mindazok müködése ellen, akik a magyarországi rutént el akarják szakitani az anyaországtól, és veszélyeztetik Magyarország területi egységét."

2. Mindazon jogok követelése, melyeket a demokratikus Magyarország a nem magyar ajkú népeknek megadni szándékozik.

3. Görögkatolikus autonómia megadása.

\footnotetext{
${ }^{2}$ Gulyás László 2018/a, 163-172.

${ }^{3}$ Bővebben lásd Botlik József 1997.

${ }^{4}$ Görög Katholikus Szemle 1918. IX. 8.

${ }^{5}$ Miklós Péter 2006, 189; Miklós Péter 2010, 153-162.

${ }^{6}$ Darás Gábor 1936, 98-99.
} 
4. Szociálpolitikai reformok a rutének szellemi és anyagi színvonalának emelése érdekében.

November 6-a után számos ruténlakta település/terület csatlakozott a Rada kiáltványához. Nézzük a fontosabbakat:

- 1918. november 21.-én a máramarosi rutének Radája, Illés Andor és Szabó Endre vezetésével.

- 1918. december 5-én az Ugocsa megyei községek közös nagyszőllősi gyülése.

A Magyar-Rutén Néptanács (a továbbiakban Rada) már megalakulásának napján felvette a kapcsolatot a Károlyi-kormánnyal.

\section{Az ungvári határozatok pozitív következményei}

A november 6-i népgyülés után a Rada politikusai és a Károlyi-kormány kifejezetten jó együttmüködést alakítottak ki egymással. Egyrészt a magyarbarát rutén politikusok valóban keresték az együttmüködés módozatait a Károlyi-kormánnyal, másrészt mind Károlyi, mind Jászi úgy gondolta és ehhez igazította rutén-politikáját, hogy a rutének számára kedvező intézkedésekkel a rutén lakta terület megtartható a magyar állam keretei között.

Ennek érdekében a magyar kormány konkrét lépéseket is tett: Az ungvári Rada javaslatára Károlyi 1918. november 17-én kormánybiztossá nevezte ki Ung megyébe Szabo Oresz belügyminisztériumi osztálytanácsost, Bereg megyébe Kutkafalvy József ügyvédet, Ugocsába Volenszky Kálmán ügyvédet, és Máramaros megyébe Illés Andor fö̈gyészt. ${ }^{7}$ Ezen kormánybiztosok egyértelműen a rutén politikai elit magyarbarát szárnyához tartoztak.

Szintén hozzákezdtek a kultuszminisztériumban egy rutén ügyosztály megszervezéséhez, illetve Bonkáló Sándor vezetésével az egyetemen egy rutén tanszék felállításának munkálatai is elkezdődtek.

Nagy jelentőségü lépés volt, hogy 1918. december 1-jén a magyar kormány Szabó Oreszt - aki addig ungi kormánybiztosként tevékenykedett -, ,, a magyarországi rutén nemzet önrendelkezési joga gyakorlásának előkészitése céljából Máramaros, Ugocsa, Bereg, Ung, Zemplén, Sáros, Szepes és Abaúj-Torna vármegyék rutén lakta területeire kiterjedö hatáskörrel" kormánybiztossá nevezte ki. Gyakorlatilag a magyarországi rutén lakta területek egy önálló kormánybiztost kaptak.

A frissen kinevezett kormánybiztos 1918. december 10-re Budapestre tanácskozásra hívta a rutén vezetőket, hogy megvitassák a rutén autonómia tervezetét. A több mint fél ezer résztvevőt Jászi utasítására a MÁV különvonattal szállította Budapestre. Ezen tanácskozás eredményeképpen született meg a „Ruszin nemzet programja" elnevezésű dokumentum, amely egyértelműn a rutének kiállása volt a magyar állammal történő további együttélés mellett. Érdemes felhívni a figyelmet a dokumentum címében olvasható ruszin kifejezésre, mely ekkor tünik fel először.

Ilyen előzmények után a Károlyi-kormány 1918. december 25-én tette közé az Országos Törvénytárban a „Magyarországon élő rutén nemzet autonómiájáról” szóló néptörvényt, mely 12 paragrafusból állt. ${ }^{8}$

\footnotetext{
${ }^{7}$ Fedinec Csilla (szerk.) 2002, 47.

${ }^{8}$ Térfy Gyula (szerk.) 1919.
} 
A törvény kimondta, hogy: „Máramaros, Ugocsa, Bereg és Ung vármegyék ruszin lakta részeiből Ruszka-Krajna néven autonóm jogterület (kormányzósági terület) alakittatik." Az így létrejövő Ruszka-Krajna (Ruténföld) a beligazgatás, az igazságszolgáltatás, a közmúvelődés, a vallásgyakorlás és a nyelvhasználat területén autonómiát kapott. Míg az ún. közös ügyekben - kül-, had-, pénzügy, állampolgárság, magán-, illetve büntetőjogi törvényhozás, gazdasági és szociálpolitika ügyek - a magyar országgyülés az illetékes. Ruténföld legfőbb kormányzati szerve a budapesti székhelyü „ruszka-krajna minisztérium”, illetve a közvetlen irányítást ellátó Munkács székhelyü „ruszka-krajnai kormányzóság.”

A minisztérium élére Szabó Oresztet, míg a kormányzóság vezetésére Avgusztin Volosint nevezték ki. Az autonóm terület legfőbb törvényhozó szerve az általános, titkos, egyenlő és közvetlen szavazással megválasztandó ruszin nemzetgyülés.

Úgy véljük, hogy a néptörvény egy rendkívül fontos állomása volt az ezeréves rutén-magyar viszonynak. A magyar állam „,de jure” autonómiát adott az ÉszakkeletFelvidék rutén lakosságának.

A törvény kihirdetése után egy nappal - azaz 1918. december 26-án - az ungvári Rada elnöke Szabó Simon táviratot küldött Budapestre, melyben a ,,ruszin nép nevében hálás üdvözletét és köszönetét” tolmácsolta a magyar kormánynak. A helyzet úgy nézett ki, hogy Jászi koncepciója - az autonómiával a magyar állam keretei között tartani a nemzetiségeket - megvalósítható.

A fentebb vázolt folyamattal - mely egy kifejezetten jó magyar-rutén viszony kiépülését mutatja - párhuzamosan olyan tendenciák is megjelentek, melyek a rutén lakta területek Magyarországtól történő elszakadása felé mutattak. Ezek következtében a magyar állam számára kedvező szituáció a következő hetekben, hónapokban gyökeresen megváltozott.

\section{A sokszereplős játszma többi szereplője és azok lépései}

A szituáció megváltozásának magyarázata abban rejlik, hogy Károlyi és Jászi törekvéseivel párhuzamosan Kárpátalja (Északkelet-Felvidék) megszerzése érdekében egy sokszereplős küzdelem bontakozott ki. ${ }^{9}$ Ebből a játszmából az alábbi nyolc momentumot érdemes kiemelni: ${ }^{10}$

Egyrészt Eperjesen és környékén olyan rutén csoportok aktivizálódtak, melyek a csehszlovák államhoz akartak csatlakozni. ${ }^{11}$ De az eperjesiek két vasat tartottak a tüzbe: jól mutatja ezt, hogy az eperjesi tanács 1918. november 8-i kiáltványában az ukrán állammal történő egyesülést szorgalmazta.

Másrészt az 1919. január 8-án Körösmezőn a környék ruténjai által kikiáltott Hucul Köztársaság egy három tagból álló küldöttséget küldött Sztanyiszlavba, hogy vegye fel a kapcsolatot az ott székelő Nyugat-Ukrán Népköztársasággal és kezdjen tárgyalásokat „köztársaságuk” a csatlakozásról az ukrán államhoz.

Harmadrészt az ukránbarát irányvonal újabb megnyilvánulásaként az 1919. január 21-i huszti rutén kongresszus egy olyan döntést hozott, mely szerint a magyarországi rutén területeket egyesíteni kell Nagy-Ukrajnával. ${ }^{12}$

\footnotetext{
${ }^{9}$ Botlik József-Dupka György 1991, 20.

${ }^{10}$ Gulyás László 2018/b, 161-166.

${ }^{11}$ Vidnyánszky I. 2010, 39-44.

${ }^{12}$ Botlik József (szerk.) 2000, 145.
} 
Negyedrészt Máramaros megye keleti részén a zömében románok lakta falvakban megfogalmazódott, hogy a területet Romániához kellene csatolni. Ez találkozott a román állam igényeivel.

Ötödrészt a frissen megszervezett csehszlovák hadsereg nyugati irányból, míg a román hadsereg keleti irányból behatolt az Északkelet-Felvidékre és abból egy-egy sávot elfoglalt.

Hatodrészt 1918 őszén az USA-ban élő ruténok - ezt nevezi a szakirodalom rutén emigrációnak - különböző csoportja és szervezetei is állásfoglaltak a területet további sorsát illetően. Közülük a csehszlovák irányzat szerezte meg a győzelmet. Ezen folyamat legfontosabb állomása az volt, hogy 1918. november 12-én az Amerikai Ruszinok Néptanácsa Scranton városában „,népszavazást” rendezett, melyen az amerikai rutén szervezetek képviselői vehettek részt. A szavazás pontos körülményeit és lefolyását a mai napig nem tárta fel a történetírás. ${ }^{13}$ Terjedelmi korlátaink miatt csupán a végeredményt rögzítjük: a résztvevők $67,2 \%$-a a csehszlovák államhoz, 28,5\%-a az ukrán államhoz történő csatlakozásra voksolt. 2,5\% akart önálló rutén államot, míg a Magyarország keretei között történő maradásra $0,8 \%$ szavazott. ${ }^{14}$

Hetedrészt a Nyugat-Ukrán Népköztársaság bejelentette igényét a magyarországi rutén területekre. Ennek jegyében 1919. január 7-én a Tatár-hágón át támadást intézett az Északkelet-Felvidéken, megszállta Körösmezőt. ${ }^{15}$

Nyolcadrészt az 1918 áprilisától novemberéig az USA-ban tartózkodó Masaryk és a Párizsban a csehszlovák államért dolgozó Beneš komoly diplomáciai lépéseket tett az Északkelet-Felvidék megszerzése érdekében. ${ }^{16}$

A fenti vázlatos felsorolásból is látható, hogy az Északkelet-Felvidék megszerzése érdekében egy sokszereplös küzdelem bontakozott ki.

\section{A csehszlovák forgatókönyv felülkerekedése}

A fenti törekvések forgatagában egyre inkább a csehszlovák megoldás felé billent a mérleg nyelve. Az emigrációjából Prágába visszatérő Masaryk, aki 1918. december 21 én foglalta el a csehszlovák állam elnöki posztját, utasította a csehszlovák haderőt Kárpátalja (Északkelet-Felvidék) elfoglalására.

Parancsának megfelelően 1919. január 12-én a csehszlovák katonaság elfoglalta a térség nyugati részét, a cseh légió 31 . számú ezrede Ciaffi olasz ezredes vezetésével pedig bevonult Ungvárra. Ez az esemény jól mutatja, hogy a Kárpátaljáért folyó küzdelemben a magyar állam fokozatosan hátrányba került a későbbi győztes csehszlovák állammal szemben.

A magyar állam esélyeit tovább rontotta, hogy 1919. március 21-én a Kun Bélaféle hatalomátvétel következtében megszületett a Magyar Tanácsköztársaság, melyet a versailles-i konferencia döntéshozói nem tekintettek partnernek.

A Tanácsköztársaság a csehszlovák és a román katonaság által elfoglalt területeket kivéve fenntartotta a magyar fennhatóságot az Észekkelet-Felvidéken. ${ }^{17}$

\footnotetext{
13 A két világháború közti magyar történetírás egy súlytalan és gyanús körülmények között lezajló népszavazásról írt, lásd pl. Darás 1936, 107-108.

${ }^{14}$ Magocsi, P. R. 1978.

${ }^{15}$ Botlik 2000, 146.

${ }^{16}$ Gulyás László 2008/a, 154-165.

${ }^{17}$ Botlik-Dupka 1991, 20-21.
} 
Direktóriumokat állított fel Bereg, Ugocsa, Máramaros és Ung megyékben, sőt 1919. április 7. és április 14. között falusi, városi és járási választásokat is rendezett.

Kijelenthetjük, hogy Kun Béláék megtartották „Ruszka Krajna” az 1918. évi X. néptörvényben rögzített autonómiáját. Ennek jegyében a Forradalmi Kormányzótanács Stefan Avgusztint - aki a Károlyi-féle Népköztársaság időszakában a terület kormányzója volt - a Budapesten székelő ruszka krajnai népbiztossá nevezte ki. Miközben a Tanácsköztársaság vezetői próbálták megtartani a rutén lakta területet, az antant engedélyezte, hogy a csehszlovák és a román hadsereg újabb területeket foglaljon el az Északkelet-Felvidéken. A csehszlovák haderő 1919. április 16-án, míg a románok április 23-án kezdtek hadmüveletekbe. Ezek eredményeképpen a Tanácsköztársaság az Északkelet-Felvidéken 40 napi fennállás után április 29-én kiszorult.

\section{A második ungvári népgyülés: 1919. május 8.}

Ebben a szituációban 1919. május 8-án Ungvárott - amely, mint azt korábban láttuk, január óta csehszlovák megszállás alatt állt - a vármegyeházában közös tanácskozásra ültek össze a legbefolyásosabb népgyülések (Eperjes, Huszt, Ungvár) képviselői. Volosin megnyitója után Szabó Simon szólalt fel és méltatta a három Rada korábbi tevékenységét. Ezután többen hozzászóltak: Viszaloczky Demeter azt hangsúlyozta, hogy a rutén nép továbbra is rutén akar maradni a csehszlovák állam keretei között. Hadzsega Illés beszédében széleskörü rutén autonómiát - a hadügy, pénzügy külügy kivételével valamennyi egyéb területen - követelt Csehszlovákián belül. Volosin munkásgimnáziumot, rutén nyelvü egyetemet és egyházi autonómiát követelt. ${ }^{18}$

A beszédek elhangzása után a küldöttek megalapították a Központi Ungvári Nemzeti Tanácsot (másik elnevezése Központi Ruszin Rada), mely kimondta a csehszlovák államhoz történő csatlakozást. A tanácskozás zárásaképpen a küldöttek elénekelték az Alekszandr Duhnovics görögkatolikus pap által írt rutén nemzeti dalt a „Ruszin voltam, vagyok, leszek”-et.

Nyilvánvaló az, hogy a csehszlovák hadsereg megszállása alatt álló Ungvár volt a tanácskozás helyszíne döntő mértékben befolyásolta a határozat megszületését. Darás Gábor könyvében azt írja, hogy a vármegyeházát csehszlovák katonák vették körbe a gyülés ideje alatt. ${ }^{19}$

A csatlakozásról készült ún. „Jegyzőkönyvet” 1919. május 20-án Prágában egy 112 tagú rutén küldöttség adta át Masaryk elnöknek. Ezzel a rutén politikai elit megkezdte pályafutását a csehszlovák politikai életben. ${ }^{20}$

$\mathrm{Az}$ ungvári és a prágai történésekkel csaknem párhuzamosan a versaillesi békekonferencia 1919 márciusában-áprilisában úgy döntött, hogy az ÉszakkeletFelvidéket Csehszlovákiához csatolja. ${ }^{21}$ Ezen döntésüket az Ausztriával 1919. szeptember 10-én megkötött saint-germaini békeszerződésbe foglalták bele. Gyakorlatilag a csehszlovák politikusok mind Versaillesban, mind a helyszínen (Ungvárott) lesöpörték a magyar állam azon törekvését, hogy megtartsa az ÉszakkeletFelvidéket.

\footnotetext{
${ }^{18}$ Darás $1936,112$.

${ }^{19}$ Darás 1936, uo.

${ }^{20}$ Toth, Andrej 2016, 57-78.

${ }^{21}$ Gulyás László 2008/b.
} 


\section{Felhasznált irodalom}

Botlik József-Dupka György 1991, Ez hát a hon... Tények, adatok, dokumentumok a kárpátaljai magyarságéletéből. Budapest: Mandátum-Universum Kiadó.

Botlik József 1997, Hármas kereszt alatt. Görögkatolikusok Kárpátalján az ungvári uniótól napjainkig (1646-1997). Hatodik Síp Alapítvány. Budapest: Új Mandátum Könyvkiadó.

Botlik József (szerk.) 2000, Egestas Subcarpathica. Adalékok az Északkelet-Felvidék és Kárpátalja XIX-XX. századi történetéhez. Budapest: Hatodik Síp.

Darás Gábor 1936, A Ruténföld elszakításának előzményei. Budapest.

Fedinec Csilla (szerk.) 2002, A Kárpátaljai magyarság történeti kronológiája 19181944. Galánta-Dunaszerdahely.

Gulyás László 2008/a, Edvard Beneš. Közép-Európa koncepciók és a valóság. Máriabesnyő-Gödöllő: Attraktor Kiadó.

Gulyás László 2008/b, Beneš statesman or charlatan? The plans and the reality 19081948. Toronto-Buffalo: Corvinus Publishing.

Gulyás László 2009, Kárpátalja történetének főbb vonásai 1918 előtt. In. Baranyi Béla (szerk.) 2009, Kárpátalja. A Kárpát-medence régiói 11. Budapest-Pécs: DialógCampus. 65-75. old.

Gulyás László 2015/a, Egy régiófejlesztési kísérlet a dualista korszakban. Történeti Földrajzi Közlemények. 2015/2. szám 191-200. old.

Gulyás László 2018/a, Az Északkeleti-Felvidék az Első Világháború időszakában, avagy rutének és a magyar állam 1914-től 1918 szeptemberéig. In. Horváth Gergely (szerk.) 2018, A magyar földrajz szerencsi mühelye. Szerencs város önkormányzata. Szerencs. 163-172. old.

Gulyás László 2018/b, Adalékok a régiótörténeti kutatásokhoz 5. A magyar állam és az Északkelet-Felvidékért (Kárpátalja) zajló geopolitikai játszma 1918-1919. In. Pénzes János (szerk.) 2018, Falu-város-periféria: határon innen és túl. Debrecen: Didakt Kft. Kiadó. 161-166. old.

Miklós Péter 2006, Vallás, politika, művelődés: Egyháztörténeti tanulmányok. Universitas Kiadó; József Attila Bölcsész Egyesület a Hallgatókért Kiadói Alapítvány. Szeged. 189. old.

Miklós Péter 2010, A forradalmak korának állama. 1918-1919. In: Szabó Pál Csaba (szerk.) A magyar állam története: 1711-2006. Szeged: JATEPress. 153-162. old.

Térfy Gyula (szerk.) 1919, Magyar Törvénytár. 1918. évi törvényczikkek és néptörvények. Jegyz. Budapest: Franklin Nyomda.

Toth, Andrej 2016, The position of Carpathian Ruthenia in the Political System of the First Czehslovak Republic on the backgraund of the Issue of Parlamentary Elections and Preferencies of Main Political Currents by Carpathian-Ruthenian Voters (1918-1938). West Bohemian Historical Review. 2016/1. szám, 57-78. old.

Vidnyánszky I. 2010, Önrendelkezési elvek és Kárpátalja állami hovatartozásának kérdése (1918-1919). In. Fedinnec Cs.-Vehes M. szerk.: Kárpátalja 1919-2009. Budapest. 39-44. old.

A müre a Creative Commons 4.0 standard licenc alábbi típusa vonatkozik: CC-BY-NC-ND-4.0. 